primary metals, and motor-vehicles and equipment; each of these industry groups employed more than 30,000 but less than 50,000 scientists and engineers. Employment of scientists and engineers in private industry was about 4 per cent higher in January 1959 than in January 1958. Engineering employment increased from about 605,000 in January 1958 to 630,000 in January 1959. The number of scientists employed in private industry increased from about 145,000 in January 1958 to 150,000 in January 1959.

\section{British Digital Computer Information Centre}

TaE National Centre of Information on Automatic Programming of Digital Computers has been established by the Department of Mathematics of the Brighton Technical College in response to a recommendation of the first National Conference on Automatic Programming held in Brighton in April 1959. The purpose of the Centre is : to establish and maintain a comprehensive library of publications; to publish, in conjunction with Pergamon Press, Ltd., an annual review of automatic programming; to provide a 'clearing house' for information and inquiries on automatic programming; to organize small working conferences on particular aspects of the subject; and to maintain permanent contact with organizations in all other countries concerned with such matters. An advisory committee to assist the work of the Centre has been established and includes Dr. A. D. Booth (University of London), Mr. R. A. Brooker (University of Manchester), Mr. P. V. Ellis (International Computers and Tabulators, Ltd.), Dr. S. Gill (Ferranti, Ltd.), Dr. J. Howlett (United Kingdom Atomic Energy Authority), Dr. R. J. Ord-Smith (Standard Telephones and Cables, Ltd.), Mr. C. Robinson (English Electric Co., Ltd.), Mr. Christopher Strachey, Mr. A. E. Taylor (Remington Rand, Univac), Mr. J. H. Wensley (Computer Developments, Ltd.), and Mr. M. Woodger (Mathematics Division, National Physical Laboratory), together with the following as corresponding members: Dr. Grace Hopper (Remington Rand, U.S.A.), Dr. L. Luckaszewicz (Mathematical Machines Laboratory, Polish Academy of Sciences), and Prof. H. Rutishauer (Institute of Applied Mathematics, Zurich). Further information can be obtained from the organizing secretary, Mr. Richard Goodman, Department of Mathematics, Brighton Technical College.

\section{Hospital Morbidity Statistics in Great Britain}

A FURTHER contribution to the study of morbidity has recently been published by the General Register Office (The Registrar General's Statistical Review of Engiand and Wales for the Year 1955. Supplement on Hospital In-Patient Statistics. Pp. vii +206. London: H.M. Stationery Office, 1959. 10s. 6d.). This volume summarizes the results of the hospital in-patient inquiry for 1955. This inquiry, which is steadily becoming more comprehensive, is expected to cover virtually the whole of the discharges of in. patients from hospitals in Britain by 1957 ; but in 1955 the hospitals that participated did so on a voluntary basis. Nevertholess the principal specialities seemed to be represented in close correspondence with the national figures, and the inquiry was fully representative of two hospital regions, East Anglia and Wales, for which special statisties are given. The statistical unit used in the inquiry is the discharge of an in-patient from a hospital, and the principal tables in the volume show the number of such discharges in various age and sex groups, and in different regions, by principal condition diagnosed. The number of deaths in hospital is shown separately, and there are data dealing with the duration of stay and the waiting period before admission to hospital. Special tabulations deal with children in hospital and maternity cases. Teaching and non-teaching hospitals are distinguished throughout. While hospital morbidity statisties are not a wholly reliable guide to morbidity, they can, as the report indicates, be of considerable assistance in the study of the mass aspects of disease, and the data will also be of considerable value to the hospital administrator. It is to be hoped that future tabulations will give information about the socio-economic status of the patients discharged. The appearance of this volume provides a valuable addition to our knowledge of the functioning of the National Health Service.

\section{Transvaal Museum}

AFTER a lapse of four years it is fortunate that it was possible once again, during $J u l y ~ 1959$, to publish the Bulletin of the Transvaal Museum. A topical article on "Excavating Ape-Men", by Mr. J. T. Robinson, describes the cave limestone in which such remains are found. The grid system of excavation is described and all bone is treated with 'Glyptal' cement immediately after it is removed from the breccia. Afterwards a 10 per cent solution of acetic acid is used to free the bones from the surrounding matrix.

\section{Musical Rites}

CERTaIN hard igneous rocks ring when struck and the note obtained depends on the dimensions of the rock itself. By careful shaping different notes can be obtained and a sort of 'glockenspiel' created. There is a decorated rock-shelter in Nigeria where such a 'glockenspiel' occurs to which parties come to be married, their faces being first carefully whitened. Dr. B. D. Malan describes just such a rock gong site in the Parys district of the Orange Free State in the South African Journal of Science (55, No. 2). It is well known that music plays a prominent part in the lives of many primitive folk; these gongs are very interesting and the resulting 'music' not at all unpleasant.

\section{The Commonwealth Scholarship Commission}

THE Earl of Scarbrough has been appointed chair. man of the Commonwealth Scholarship Commission in the United Kingdom. The Commission is to be set up under the Commonwealth Scholarships Act, 1959, recently passed by Parliament, to administer the Commonwealth Scholarship and Fellowship Plan in Britain. This Plan was worked out by the Commonwealth Education Conference at Oxford in July 1959 and creates a thousand new postgraduate awards throughout the Commonwealth. Of these, the United Kingdom will contribute five hundred scholarships and fellowships tenable in the United Kingdom at any one time.

\section{University News:}

London

DR, G. V. R. BorN, research officer at the Nuffield Institute for Medical Research and departmental demonstrator in the Department of Pharmacology in the University of Oxford, has been appointed to the Vandervell chair of pharmacology tenable at the 